\title{
Notes on corona crisis and temporality
}

\section{Josep Maria Antentas ${ }^{1}$}

Published online: 7 September 2020

(C) Springer Nature B.V. 2020

The coronavirus crisis has put the discussion of the notion of crisis itself back at the center of the debate. The concept of crisis is derived from the Greek verb krino that means to "separate," "choose," "judge," or "decide," As Koselleck $(1988,2012)$ has explained its different meanings in ancient Greece, all somehow suggested the absence of time and a moment of truth and decision - its medical Hippocratic meaning being the one that historically prevailed, referring to the critical moment when illness could get worse and lead to death or could ease off and lead to recovery. Crisis was, in that sense, a turning point with opposing possible outcomes. A crisis marks a milestone in a society's trajectory, whose depth is proportional to the crisis itself. Returning to the original meaning of the term is useful to take into account that every crisis is settled by a process of reorganization of social (and geopolitical) relations, whose concrete outcome depends on the balance of forces between the different sociopolitical projects at stake. That is the crucial question regarding the debates on the world after the pandemic.

In its contemporary conventional uses in politics and social sciences, crisis no longer refers to this turning point towards different dénouements, but rather a moment when a given situation worsens. Crisis thus merely describes the opposite pathological state to the normal. But the fact is that the normality of capitalism is already pathological, first because it regularly leads to crises and second because it creates everyday suffering and inequality. Walter Benjamin (1999[1927-1940]:473, [N9a,1]) in his Passagenwerk noted this everyday twosided pathological normality of capitalism when writing that "the concept of progress must be grounded in the idea of catastrophe. That things are 'status quo' is the catastrophe. It is not an ever-present possibility but what in each case is given. Thus Strindberg (in 10 Damascus?): 'hell is not something that awaits us, but this life here and now'."

The topological figure of bifurcation is critical to understand the historic meaning of crises as they represent a turning point towards the uncertain where alternative paths become possible. Several authors have recently made use of the concept to explain the dilemmas of global capitalism in terms of competing future possibilities. The cases of Wallerstein, Balibar, and Bensaïd are noteworthy. All of them rest upon certain usages of mathematics bifurcation theory associated to catastrophe theory, whose main exponent was mathematician René Thom

Josep Maria Antentas

josepmaria.antentas@uab.cat

1 Department of Sociology, Centre d'Estudis Sociològics sobre la Vida Quotidiana i el Treball (QUIT)-Institut d'Estudis del Treball (IET), Universitat Autònoma de Barcelona (UAB), Bellaterra, Spain 
(2014[1980]), and to the theory of dissipative structures in the study of complex systems out of equilibrium done by Ilya Prigogine (Prigogine and Stengers 1997). Wallerstein (2004) employed it to study the unbalances of the world system. Balibar (2006, 2015) has also utilized it as a metaphor to describe what is at stake regarding the future of European societies and global capitalism. Bensaïd $(2001,2008)$ also insisted on the notion of bifurcation, relating it to an anti-teleological conception of history as an open road, full of crisis and discontinuities of uncertain outcome.

The specificity of Bensaïd's interpretation is that crises and bifurcations are thought strategically, following a political reading of Benjamin's classic thesis on the concept of history of (Benjamin 1940). Inspired by Benjamin Bensaïd (2010[1990]), he postulates a "strategic politics of the present." Time par excellence of politics, the present is the juncture where historical bifurcations are settled. Understood as a bifurcation, crisis is precisely a moment of truth - a moment where several alternative futures collide in the present. The moment of truth, the moment of judgment and decision, usually with an absence of time. This was, as said above, the essence of the classic concept of crisis. For Thucydides, the Greek historian and general, the fight between powers was settled in decisive battles (Koselleck 1988). In his History of the Peloponnesian War about the wars between Athens and Sparta in the fifth century $\mathrm{BC}$, he uses the term crisis to refer to the four decisive battles (two naval and two terrestrial), and he also uses the same term to describe the plague that shook Athens in 430 BC. In this moment of truth, however, not all sides have the same chances. Although today neoliberalism has a great crisis of legitimacy, it is worth to recall that in times of crises, as Gramsci (1971: 451) wrote "the traditional ruling class, which has numerous trained cadres, changes men and programs and, with greater speed than is achieved by the subordinate classes, reabsorbs the control that was slipping from its grasp."

Crises are moments of simplification of social relations and clarification of reality. They reveal the hidden which we usually do not see. They make it possible to clarify the nature of relationships and social structures. They shed light on those evidences that we take for granted and unravel the mysteries of society. Appearance and essence, if we take up Marx's expression in Volume III of The Capital ("If there were no difference between essence and appearance, there would be no need for science"), seem to be provisionally unified. The 2008 crisis made the logic of the financial system visible, the current one has shed light on social reproduction.

Presentism, defined by François Hartog (2012 [2003]) as a regime of historicity characterized by the extension of the present, by a hypertrophied present that invades the horizon, is the temporal logic of global capitalism. The crisis of the COVID-19 modifies the nature of presentism, since our extended and endless present has been abruptly invaded both by the past (the confinement and the virus evoke situations that we associate with the great pandemics of the past) and by the future (which suddenly appears in the form of an abyss and a catastrophe to come). The lockdown not only interrupts the normal flow of activity; it also interrupts the inertia of the present. With this, the inexorability of an inert future becomes frozen, and a scenario of bifurcations and contingencies opens up.

The lockdown has been both a sudden halt and an acceleration, a paralysis of a large part of socioeconomic relations and at the same time a deepening of social inequalities (i.e., the unequal distribution of care work) and of the previous trends underway (digitalization, etc.). The virus acts as an accelerator of tendencies, as a precipitator, like a wormhole where stages are skipped and in which the leaps forward also modify the final result. It is not a linear acceleration, but a syncopated, catastrophic one, which hastens a phase change. 
The crisis of civilization in which humanity finds itself implies a concatenation of crises in time and a chaotic overlapping of several crises at once (health, economic, social reproduction, ecological, etc.). In this multidimensional crisis, different discordant temporalities (and spatialities) are interwoven (Bensaïd 1995, 1997). But, at the same time, every crisis is a moment of temporal unification and simplification, of condensation, and of social contradictions. The lockdown has thus been a moment of simplification-unification of social temporality, but on a background of discordant temporalities. Underlying the sudden deceleration of our subjective experience is a decoupled and unstructured temporality that reveals the contradictions of global capitalism.

The pandemic has brought with it a strange sense of paradoxical familiar unknown novelty. It is an experience that we have never lived but that we have imagined and seen in fiction a thousand times. At the same time, the simultaneous perception of living an unknown moment and a foretold catastrophe has been coupled. It seems to bring up-to-date atavistic fears (death, contagion, etc.) but in a hyper-technological and accelerated environment. The lockdown transforms the experience of time and slows down its subjective experience but in a background of uncertainty. It implies a contradictory space-time fusion of all the dimensions of our life (i.e., home transformed into a place of productive work and children's school) which highlights the irrationalities of the socio-temporal organization of our social model and the profound inequalities, of class and gender, that underlie it.

The COVID-19 crisis shows the fragility of existence and reminds us of our own corporeality. The centrality of death reverses priorities and concerns. The breakdown of routines is an occasion to reflect on the world taken for granted, to take distance from one's own daily life and our social model. But the advantages of distancing oneself from our world are threatened by the attraction force of attention capitalism (Wu 2017) and by the fact that sociopolitical learning always has a collective dimension and is related to the processes of social struggle that precisely the lockdown itself makes difficult - hence the critical importance of the limited experiences of mutual aid and self-organization in confronting the difficulties that have taken place in many countries.

Nor a simple painless annoyance or an inevitable final apocalypse either, crises should be better understood in prophetic terms. So conceived, as Hartog (2013) explains, there is a way out of crisis, a poros (i.e., a passage, an exit), but whose concrete form is still uncertain and conditional. The very nature of prophetic warning is conditional, and this enables, as does Bensaïd's (2001: 241) strategic Benjaminian political Messianism, to understand crisis as "a moment of the rupture of continuity" and "great passage" where "the constraints of the situation and the contingencies of action" meet. History is an open road that is not written beforehand. It signals an open itinerary, full of crossroads, dead-end roads, and false shortcuts - the final outcome being the result of political and social struggle.

\section{References}

Balibar, Etienne. 2006. Strangers as enemies: further reflections on the aporias of transnational citizenship. In Globalization Working Papers 06/04. Hamilton: Institute on Globalization and the Human Condition.

Balibar, Etienne. 2015. 'Two roads for Europe: an interview with Étienne Balibar', 10 august. https://www. versobooks.com/blogs/2169-two-roads-for-europe-an-interview-with-etienne-balibar.

Benjamin, Walter. 1940. 'On the concept of history'. https:/www.marxists.org/reference/archive/benjamin/1940 /history.htm.

Benjamin, Walter. 1999[1927-1940]. The arcades project. Harvard: Harvard University Press. 
Bensaïd, Daniel. 1995. La discordance des temps. Paris: Éditions de la Passion.

Bensaïd, Daniel. 1997. Le pari mélancolique. Paris: Fayard.

Bensaïd, Daniel. 2001. Résistances. Paris: Fayard.

Bensaïd, Daniel. 2008. Penser Agir. Paris: Lignes.

Bensaïd, Daniel. 2010 [1990]. Walter Benjamin, sentinelle messianique. Paris: Les Prairies Ordinaires. Gramsci, Antonio. 1971. Selections from the prison notebooks of Antonio Gramsci. London: Harbour. Hartog, François. 2012[2003]. Régimes d'historicité. Paris: Points.

Hartog, François. 2013. Crises du temps, crises dans le temps. In Crises? 11-26. Paris: Éditions Parenthèse.

Koselleck, Reinhart. 1988. Critique and Crisis. Boston: MIT Press.

Koselleck, Reinhart. 2012. Historias de conceptos. Madrid: Trotta.

Prigogine, Ilya and Isabelle Stengers. 1997. End of Certainty. New York: The Free Press.

Thom, René. 2014. Parables, parabolas and catastrophes: conversations on mathematics, science and philosophy. Toronto: Thombooks Press.

Wallerstein, Immanuel. 2004. World-systems analysis. An introduction: Durham, Duke University Press.

Wu, Tim. 2017. The attention merchants. London: Random House.

Publisher's note Springer Nature remains neutral with regard to jurisdictional claims in published maps and institutional affiliations. 